\title{
BOYCOTT OF THE LOS ANGELES 1984 OLYMPIC GAMES AS AN EXAMPLE OF POLITICAL PLAY-ACTING OF THE COLD WAR SUPERPOWERS
}

\begin{abstract}
Sports boycott is one of the most important dimension of sport colliding with politics. The subject of the article is the boycott of the Los Angeles Olympic Games in 1984, one of the most spectacular boycotts, which was conducted by communist countries.

It is widely recognized, that Los Angeles Olympics were boycotted as a result of a similar action by Western countries towards Moscow Olympics in 1980. However, evidence proves that there was no decision concerning communist boycott of Los Angeles Olympics until a few months before the Games. Preparations to the Olympics were on their way, but unexpected change of Soviet leader resulted in the boycott.

Safety reasons were the declared reason for the boycott of the Soviet Union and 13 other communist countries. Nevertheless, it is evident that the real reasons were connected with the political game of USSR. The probable actual aims were the desire to hit the first ever privately financed Olympic Games and to make it harder for American president Ronald Raegan to be reelected. Naturally, at least partly it was also a matter of revenge for boycotting the Moscow Games.
\end{abstract}

Keywords: Sports politics, sports boycott, Cold War rivalry, Olympic Games, politics

\footnotetext{
* University of XXXX.
} 
Sports boycott is one of the most spectacular examples of sport and politics colliding. States or respectively their leaders may derive political benefits from sport - through winning competitions or many medals on international sports events or through particular victories in prestigious contests. Political benefits, especially in the area of image and prestige, may be also derived from organizing sports events, as they seem to be an efficient mean of worldwide promotion of a state, or in some cases - its political system. The political dimension of sports boycott is completely different. However, according to various factors, its political significance may even be greater.

A sports boycott should be understood as a resignation from participating in a particular sports event as a result of a protest. From the historical perspective there were various types of sports boycotts. Their scale differed from minor ones involving one state only, to massive ones, when big group of countries refused to participate in an event. However, there have also been individual boycotts, when single athletes or political figures resigned from participating in the sports competition, as happened during recent Olympic Summer Games in Beijing 2008 or Olympic Winter Games in Sochi 2014. In those situations various politicians in protest against the policy of a country that hosted the event decided not to be present during the opening ceremonies. There have also been various subjects against which the boycotts were directed. During the Cold War era some of them were tightly bound with the pure ideological rivalry between East and West. Others should be regarded as protests against particular events of the international politics, therefore they were directed against the responsible states or the sports organizations, due to their lack of reaction to the political occurrences. Boycotts conducted by African states were characteristic, as they were aimed to achieve particular political goals such as condemnation of white minority governments in Africa. Sports boycotts were then the reflection of changes in the international political system as they were usually the results of political crises.

The essence of sports boycott is the use of relatively simple method, thanks to which in a very far-reaching way one may draw attention of the world to a particular problem. At the same time, it is an easy way put pressure. According to some authors, "sports boycott is the only one that 
is effective as sport is a cheap way to boycott" (Gemmell, 2004, p. 124). Sports boycott is often described as politically useful and not expensive mean of demonstrating dissatisfaction (Guelke, 1986, p. 143).

Boycotts of the Moscow Olympics in 1980 and Los Angeles Olympics in 1984 are the best known to public. The latter example is the main subject of the article. The aim of the article is to investigate the decision of the communist states concerning the boycott of the Olympic Games in Los Angeles in 1984 -held on the soil of their ideological rival - the USA. It is widely believed that it was a sort of a payback for the boycott of the Olympics organized by the Soviets four years earlier in Moscow. There is a doubt though, whether it was in fact purely a revenge by the Soviet leaders, or the decision was also influenced by other factors. The article is then aimed to point the actual reasons of the boycott of the Los Angeles Olympic Games, apart from the declared ones. An attempt to answer, whether the boycott was prejudged form the moment Moscow Olympics were boycotted by the USA and some of its allies or the decision was made later, will also be ventured. The research will also include the issue of diplomatic activities, particularly of the International Olympic Committee and the organizers of the Olympics, that were aimed to prevent or reduce the size of the boycott. Also, an attempt to evaluate the effectiveness of the boycott of the Los Angeles 1984 Olympics will be made.

The research will be conducted with the use of cybernetic approach within the decision-making method. Accordingly, the communist decision to boycott the Olympics will be investigated considering such issues as the rational interest, emotions and personalities of the decision-makers (Pietraś, 1998, p. 29). Also, the research will encompass an attempt to determine the subject of the final decisions, which is not obvious in some cases.

\section{ORIGINS OF THE LOS ANGELES 1984 BOYCOTT}

In 1980 the biggest sports boycott ever took place. It concerned the Olympic Games organized for the first time in the Soviet Union - in its capital city Moscow. The boycott itself was deeply bound with the Soviet intervention in Afghanistan in 1979. American president Jimmy Carter 
first demanded the withdrawal of Soviet troops, but when it did not happen, he led to the boycott of this sports event by the United States and a number of other countries. According to various authors between 45 and 65 states decided to resign from participation in the Olympics as a result of the boycott declared by Jimmy Carter (Miller, 2008, p. 258; Lipoński, 1996, p. 62; Glad 2009, p. 211; Espy, 1981, p. 195; Guttman, 2002, p. 153-154; Moscow 1980). Obviously such situation was not desired by the Soviet Union. Nevertheless, this communist country did not settle for a preemptive strike and participated in the organized by Americans Olympic Winter Games in Lake Placid earlier in 1980, although they were held when the threat of the boycott of Moscow Games was already credible.

The Summer Olympics in 1984 were to be held in the United States, in Los Angeles. Such location may have had suggested the possibility of a sort of a payback by the states belonging to the communist bloc of states. Such view is represented by many scientists investigating this issue and such is the common view. The issue is much more complex though and requires more detailed overview.

The election of Los Angeles as the host of the next Olympic Summer Games after those in Moscow could be regarded as a kind of compensation for the election of the Soviet capital city. However, Los Angeles was the only city interested in hosting the Summer Olympics in 1984, as the other bid - Iranian Teheran - was withdrawn before the candidacies were considered (Jennings, 2012, p. 173; Garcia, 2012, p. 55; International Olympic Committee, 2011, p. 62). The bid of the California's biggest city was unusual, as it was private. The city's authorities did not agree to subsidize the Olympics. In the face of a crisis of the Olympic Movement after a number of African states boycotted the Olympics in Montreal in 1976, the IOC agreed to such solution and in 1978 elected Los Angeles as the future host of the Olympic Summer Games (Miller, 2008, p. 255). The decision of the Committee was not a compensation to the West for the Olympics in Moscow then. However, Los Angeles' bid would probably be one of the favourites for the election anyway, as it was applying to host the Olympics in 1976 (it was then evaluated as too inexperienced) and 4 years later, both times unsuccessfully (Hill, 1996, p. 139). Apart from that, at the time of the election (1978) there was still détente between East and West. 
Therefore nothing suggested the future boycott of Moscow Olympics, so it was hard to envisage that the Los Angeles Games would also face such threat.

\section{THE PATH TO THE BOYCOTT}

The possibility of a boycott of the Los Angeles Olympics was under discussion in the Soviet Union from the moment, when Jimmy Carter for the first time declared his intention to boycott the event in Moscow (Guttmann, 2002, p. 157), which was in January 1980. Some of the Soviet leaders were reported to have said that Carter must have known, that the American action against the Olympics would probably cause the Soviet boycott of the next Games (Caraccioli, Caraccioli, 2008, p. 116). Similar information appeared in Soviet press (Whitney, 1980, p. 38). The assumption that resignation from participating in the Olympic Games in Los Angeles by the communist states was considered as on option from the moment when the threat of boycott of Moscow by the capitalist states appeared seems credible then.

The Olympics in Los Angeles were then expected to become an arena of sports boycott. However, despite initial suggestions about the possibility of boycotting Los Angeles Olympics, the issue was not undertaken at all for more than three years. Moreover, during the IOC Session in New Delhi in 1983 Roman Kiselov from the Soviet National Olympic Committee assured that his country would come to Los Angeles (Lipoński, 1996, p. 66). Critics concerning American organizers of the Games only occurred in the Soviet press, where the issues of lack of the Olympic Village situated in a single location, low level of security, big distances between the venues and polluted air were raised. At the same time there have been many contacts between the organizers of the Olympics and sports officials from the USSR and other communist countries. First of such took place in 1979 when the president of the organizing committee Peter Ueberroth visited Moscow during a Spartakiad (Chruścicki, 1987, p. 6). Despite American boycott of the Moscow Olympics such visits were not terminated, for instance in February 1982 P. Ueberroth visited East Germany. During his stay a pro- 
tocol was signed, according to which East German athletes were supposed to compete in Los Angeles as long as the organizers would not violate the Olympic Charter. Although there were more such agreements, it was obvious that the final decisions depended on Kremlin (Hill, 1996, p. 172, 179). It is worth noticing, that the organizers of the Los Angeles Olympic Games began a kind of diplomatic offensive aimed to avert the boycott in advance, although the issue officially was not raised at all.

In December 1983 an important meeting between the Soviet officials and the organizers occurred - 14 delegates from the USSR paid an 8-day visit in Los Angeles. The meeting resulted in singing a protocol of agreement, according to which the Soviet National Olympic Committee pointed its expectations concerning the Soviet participation in the Olympics and expressed a desire to negotiate the issue of accommodation (Hill, 1996, p. $172,179)$. During the visit one of the Soviet delegates Marat Gramov was to have said that his attitude towards the Games was positive and that he saw no reason why the Soviet Union should not participate (Reich, 1984, p. 18).

In January 1984 another delegation from the USSR visited Los Angeles, this time in order to meet the IOC Executive Commission. The Soviet side requested Americans to accept Olympic identity cards instead of visas, agree that the Soviet airlines Aeroflot would jet the athletes to the Olympics and accept a USSR ship in the Los Angeles harbour (Hill, 1996, p. 172). So, the contacts between Soviet and American side were lively. It must be said that the USSR did not demand anything impossible to be fulfilled. Also, there were no mentions about the boycott. These facts imply that decisions concerning the boycott of the Los Angeles Olympic Games were not necessarily made in 1980 or were delayed due to tactical reasons.

Another chapter of the events was held during the International Olympic Committee Session in Sarajevo in February 1984, shortly before the Olympic Winter Games in the same city. The event proved to be important concerning the issue of possible Los Angeles boycott. Surprisingly to everyone, Soviet IOC Member Konstantin Adrianov stated, that the organizing committee of the Los Angleles Olympics did a great job and despite the fact, that the Soviet Union was critical in the past, it could now congratulate the organizing committee. Some of the IOC members considered the state- 
ment as the declaration that the USSR would participate in the Olympics. However, a few days later the Soviet leader Yuri Andropov passed away and his place was taken by Konstanin Chernenko (Reich, 1984, p. 19). This occurrence can be perceived as a ground-breaking moment in respect to the Soviet attitude towards the possibility of participating in the Olympic Games in Los Angeles. In fact, the threat of the Soviet boycott as a payback for American one could be seen already during the Olympics in Sarajevo (Miller, 2008, p. 275). As a matter of fact, K. Chernenko represented the Kremlin hawks, what might have had a negative impact on the developments. Peter Ueberroth confirmed that the change of the Soviet leader was a critical point concerning the situation. According to him, from then on the communication between the organizing committee and the Soviet Union was gradually deteriorating (Reich, 1984, p. 19). The so far flourishing dialogue was no longer sustained.

Until the beginning of 1984 the expectations concerning the possibility of the communist states competing in the Los Angeles Olympics were optimistic. An important occurrence was held earlier though. On September 1, 1983 a Soviet air fighter shot down South Korean airliner after it violated the Soviet airspace over Sakhalin. 249 passengers and 23 members of the crew died in the tragedy (Cheney, 2006, p. 32). The occurrence worsened the American-Soviet relations. For example, legislative authorities of California (where Los Angeles lies) issued a resolution condemning the Soviet Union. The resolution included a statement calling to ban the USSR from participating in the Summer Olympics in 1984. Although the statement was cancelled shortly after its release, the Soviet Union responded by withdrawing its athletes from all sports events that were to be held in 1983 in Los Angeles (Wilson, 2004, p. 211).

The shootdown of the Korean airliner had another, probably even more important repercussion - the creation of Ban the Soviet's Coalition. It was a marginal organization whose aim was to prevent the Soviet Union from participating in the Olympics. Accordingly, it organized manifestations and collected signatures, although it only managed to collect 10.000. Still, it was to play a role in respect to the boycott of the Los Angeles Olympic Games by the communist states (Hill, 1996. p. 171; Wilson, 1996, p. 173). Despite such developments the issue of the boycott still was not raised by 
the Soviet sports officials, who until Andropov's death implied that Soviet Union and other communist states would compete in the Games.

As mentioned, the situation was getting tensed since the Games in Sarajevo. In march 1984 Americans denied visa to Oleg Yermishkin, who was proposed by the USSR as the Olympic attaché. Americans however identified him as an operational officer of the KGB (Guttman, 2002, p. 159). At the beginning of April Soviet press amplified its criticism concerning the preparations of the Los Angeles Olympic Games. Its main concern was about the safety of the Soviet athletes. The culmination point of this campaign was at April 9, when the Soviet National Olympic Committee gave a statement, according to which a campaign directed against the Soviet participation in the Games arouse in the USA, characterised by threats of physical violence and persecution of the athletes representing the Soviet Union. Soviet officials also raised the issue of the procedure of entering the USA by the Soviet delegation. According to them, it violated the Olympic Charter. At the same time the Soviet side demanded organizing an additional meeting of the IOC Executive Commission in order to ascertain that USA would obey the principles of the Olympic Charter (Wilson, 2004, p. 211-212). This occurrence can be regarded as the beginning of the Soviet operations towards boycotting the Los Angeles Olympics, as for the first time they criticized the organizers of the event in such a strong manner, at the same time raising its political aspects.

The meeting requested by the Soviet Union was held at April 24, 1984 at the IOC main office in Lausanne. The organizers of the Los Angeles Olympic Games were represented by Peter Ueberroth, while the Soviets by Marat Gramov, chair of the Soviet NOC and minister of sport. At the press conference Gramov reported, that some problems, which he did not mention, still need to be solved before the final decision concerning the Soviet participation in the Olympics would be made. He also said, that the Soviet NOC received many declarations and letters from various nationalistic and terrorist groups and organizations with threats (Reich, 1984, p. 19). As can be seen from the statement, the meeting did not bring any meaningful solutions or declarations.

At April 29, 1984 M. Gramov sent a secret letter to the Central Committee of the Communist Party, in which he stated that the preparations 
of the Los Angeles Olympic Team were in progress, but mentioned as well, that there was a risk that anti-Soviet organizations might use violence and encourage Soviet athletes to come to their side. The document also included a statement, that "the participation in the Games would be difficult if the hostile activities would not be ceased and that the absence of the USSR and developing countries would bring the first 'commercial Olympics' to economic catastrophe (...) if the [safety] conditions would not be fulfilled we will resign from participating" (Miller, 2008, p. 275). The document together with handwritten comments allow to partly recreate the decision-making process. The statement about the possible economic catastrophe of the commercial Olympic Games seems exceptionally important. Obviously such Games were aimed most of all to earn a profit rather that to promote a city or a country, as it usually happens. However, the document also mentioned the continuation of the preparations to the Olympics and the possibility of competing in the Games. Probably at the time the final decision still was not made.

At May 8, 1984 the Soviet NOC gave an announcement, according to which it would not compete in the Olympic Games in Los Angeles. As it stated, "the anti-Soviet hysteria arouse in the United States; extremist groups and organizations of different types trying to create impossible to accept conditions of Soviet athletes participation increased its activity; the American side shows it does not intend to grant security to the athletes and to respect their rights and human dignity; in such conditions the National Olympic Committee of the Soviet Union is forced to declare, that participation of the Soviet athletes in the Olympics is impossible". There was no reference to the payback as a cause of such decision. As Gramov who presented the announcement stated, it was the decision of the NOC (Guttmann, 2002, p.157). It is doubtful though, as the final document was signed by the Secretary of the Central Committee of the Communist Party - Konstanin Chernenko, while the initiators of such decision were supposedly head of the Soviet diplomacy Andrei Gromyko and chief of Soviet NOC Marta Gramov (Miller, 2008, p. 275-276). The decision itself most probably was made in the Politburo at May 3 (Senn, 1999, p. 197). Therefore, the decision was made on Kremlin, not in the formally responsible National Olympic Committee. 
Shortly after the decision of the Soviet Union was announced, the organizers of the Olympics and the International Olympic Committee undertook various activities in order to ensure that as many countries as possible would participate. The situation was similar to the one four years earlier. Coincidently, at the same day of the Soviet announcement, American president Ronald Reagan handed president of the IOC Juan Antonio Samaranch a letter with assurance, that the USA would obey all the rules and principles of the Olympic Charter and that safety of the athletes and officials would be granted. Samaranch, a former diplomat and ambassador of Spain in Moscow, probably hoping for a change of decision, wanted to personally hand the letter to Chernenko. Therefore he requested for a meeting (Reich, 1984, p. 18). While waiting for a response he went to Prague with the delegation of the IOC in order to persuade other communist states to participate in the Games. He did not achieve much though (Miller, 2008, p. 276), but he received an invitation from the Soviet minster of foreign affairs A. Gromyko (Talk on Olympics..., 1984, p. 3). He headed to Moscow at May 30 for the last chance talks. Despite having diplomatic contacts, Samaranch did not manage to meet neither Chernenko nor Gromyko, but he met one of vice-prime ministers Nikolai Talyzin and Martat Gramov. At the time the deadline of declaring participation in the Los Angeles Olympics was approaching, but Samaranch was ready to postpone it. Nevertheless the talks failed anyway. As Samaranch reported, before he flew to Moscow the chances of the USSR competing in the Games were very, very small, but after them there was no chance at all (No hope for Soviets..., 1984, p. 8). The final settlement was easy to anticipate, but still an attempt was made to change the situation in the last moment.

At the same time organizers of the Los Angeles Olympics began their operations in order to persuade to come to the Games as many countries as possible. Their head Peter Ueberroth established a goal, according to which more countries should participate than during the Olympic Games in Munich in 1972, before the era of boycotts. To that end the organizing committee created a 24-hour open phone center responsible for persuading National Olympic Committees to participate in the Games. Also, agents were sent abroad and American embassies worldwide were engaged. Those 
activities proved to be at least partly successful, as at May 12 Peoples' Republic of China informed that it would compete in the Games (for the first time since 1952), while a few days later Romania declared the same (Wilson, 2004, p. 212). According to P. Ueberroth, "Africa was the most important area. We told them, that boycotting our Games would impact negatively on the attitude towards South Africa (...) we could have paid the Third World (...) Presence of Romania can be owed to 3 people: Samaranch, Siperco ${ }^{1}$ and Agnes Murza, our agent in Romania. She managed to establish relations with their officials". The agents mentioned were sent to every hesitant country and according to the strategy, they were to be strongly bound with the country they headed to - they were to know the language, culture and business (Miller, 2008, p. 275). It should be noted that one of the strategies was also used by the Soviet Union before the Moscow Games - less wealthy countries were receiving financial aid that would allow them to send teams to the Olympic Games in Los Angeles.

The decision of Romania to send its team to the USA was in a way an unexpected exception if communist countries under Soviet influence are taken into consideration, as most of them decided to join the Soviet boycott. It was regarded as a great risk of Romanian leader

Nicolae Caucescu (Miller, 2008, p. 275). As a result, Romanian athletes were receiving a standing ovation during the Games. As should be mentioned, Romanian athletes performed exceptionally well in Los Angeles and were ranked $3^{\text {rd }}$ in the unofficial medal table. The country also benefitted from the financial aid program by the organizers and the IOC, which covered a third part of the cost of sending the team to the Olympics, estimated to be about 180.000 USD (Hill, 1996, p. 154). The other European communist country that was present at the Games was Yugoslavia, although it was obviously not within the Soviet sphere of influence (Mallon, Hejimans, 2011, p. lxxv). All other communist European states acted according to the Soviet Union's line. East German NOC decided not to participate at May 10,2 days after the Soviet announcement (Wilson, 1988, p. 160). Poland and Hungary were considering sending teams under the Olympic flag, similarly to some of the states in Moscow (such as the Great

\footnotetext{
1 Alexandru Siperco, IOC Member from Romania.
} 
Britain), but in the end they withdrew from the Games: Hungary at May 14, Poland at May 17 as the last country from the communist block of states. According to Tadeusz Olszański, who was present at the meeting when the decision was made, he had no doubts it had been made outside of the NOC. The pressure from Moscow could be seen in the materials promoting the Friendship Games, a sports event planned to substitute the Olympics. As a result there was no voting and decision was made by Marian Renke, president of the Polish Olympic Committee, although according to Olszański he made the decision "suffering" (Olszański, 2000, p. 162-166). According to Janusz Peciak, Olympic champion who had suffered from the boycott as an athlete, $M$. Renke has told him a few days after Polish decision to withdraw from the Olympics that he agreed "it was horrible but he had no choice and that the boycott was an order from Moscow" (Wawrzynowski, 2015). It may be assumed then, that the decision was imposed by the Soviet leaders. Only a few reporters from Poland were sent to Los Angeles, but most of the transmissions from the Olympics were broadcasted on the radio, while television only showed short fragments (Tomaszewski, 1992, p. 235).

In 1982, 2 years before the Olympics in Los Angeles, Polish Olympic Committee has published a book dedicated to Polish Olympic preparations - Polski Sport Olimpijski. Polish Olympic Sport. Los Angeles 1984. It was about athletes' trainings and the medal hopes. This may imply that the boycott was not planned in Poland since the Moscow Olympics either. This seems to back the thesis that the decision about the boycott was probably made much later and should not be regarded as a simple payback by communist states. It was most probably after the Andropov's death when the boycott became an option.

Apart from the Soviet Union, the following countries decided to boycott the Olympic Games in Los Angeles: Afghanistan, Bulgaria, Cuba, Czechoslovakia, Ethiopia, East Germany, Hungary, Laos, Mongolia, North Korea, Poland, South Yemen and Vietnam (Mallon, Hejimans, 2011, p. lxxv). The size of the boycott (14 countries) was not as massive as in Moscow, however it should be noted that those 14 countries won $58 \%$ of all gold medals during the Olympics in Montreal in 1976 (Los Angeles 1984). As many as 140 states participated in the Games, but the number is slightly 
exaggerated due to the fact, that some of the territories were granted the possibility to compete in the Olympics even though they did not fulfil the requirements of the Olympic Charter (Toohey, Veal, 2007, p. 101; Guttmann, 2002, p. 160).

The decision by the Soviet Union and its allies about boycotting the Olympic Games in Los Angeles had a strong impact on the organizers. However, the situation was not seen as critical. The sponsors were acting normally and the official broadcaster $\mathrm{ABC}$, which seemed to be most exposed to the results of the boycott, underlined the possible benefits of more medal chances for Americans (Hill, 1996, p. 154). Generally speaking Americans were rather optimistic concerning the Games despite the upcoming boycott by the communist states.

Judging by the numbers, the Soviet Union did not succeed fully in its mission of persuading many countries to back the boycott, similarly to the USA 4 years earlier when a number of American allies participated in the Moscow Games, often against the will of their governments. In this case Romania did not obey the dominating line, and what is more, most of the non-aligned countries joined the boycott. The number of states participating in the Games was also remarkable, although due to a sort of manipulation, as was said earlier.

The reasons for Soviet decision concerning the boycott of the Los Angeles Olympic Games are subject to many researches. The main declared reason was the insufficient safety of the athletes from communist countries. It was undoubtedly only a camouflage for the actual reasons. According to Alfred Senn, the decision probably emerged from the traditional Soviet superpower policy, a desire to lower the chance of re-electing Ronald Reagan for president and to limit the revenues of the organizing committee (Senn, 1999, p. 198). The last aim seems to be the most credible, as it was also mentioned in the secret document mentioned above. However, there are also other opinions concerning the possible reasons for the boycott. Some authors speculated, that Soviet leaders might have feared a sports loss, but considering the results achieved by athletes from communist countries at the time, this hypothesis does not seem credible (Guttmann, 2002 , p. 159). Vast majority of the authors agree though, that it was generally a payback for boycotting the Moscow Games four years earlier. On 
the other hand, continuing sports preparations to the Games may negate such view. A change of Soviet leader must be taken into consideration though. At the time of the Moscow Olympics boycotted by the West the Communist Party was headed by Leonid Brezhnev. After his death in 1982 Yuri Andropov, who was regarded as more liberal, took over. In February 1984 he also passed away and conservative Konstatnin Chernenko was elected to head the country. Instantly a change in the Soviet attitude concerning the Olympics in Los Angeles could be observed. President of the IOC Juan Antonio Samaranch said once, that "if Andropov was alive, I think that we wouldn't have a problem in 1984" (Miller, 2008, p. 275). Chernenko was a close associate of Brezhnev, so it might be assumed that one of the reasons for his decision was a desire to take revenge for boycotting Moscow. As Peter Ueberroth recalled, after the American boycott of Moscow Olympics was declared, one of the Soviet dignitaries have said: "Sometimes you call us a bear, a large bear. Now you can call us an elephant because we never forget" (Reich, 1984, p. 20). If it was true, these words might have suggested having made a decision concerning the future boycott at the time. The change of the Soviet leadership in the time between the Olympics might have led the Soviet Union to resign from its desire for payback, but in the end the conservative members of the Soviet leadership were in charge.

Despite the boycott, the Games earned a profit of over $200 \mathrm{mln}$ USD, according to some analyses even more than 222 mln USD (Guttmann, 2002, p. 163; Kumar, 2007, p. 315, Delaney, Madigan, 2009, p. 255). This way the Los Angeles Olympics set new standards in organizing such sports events in the future. Building the budget upon selling the television rights was one of the novelties. It constituted one third of all the incomes of the Games (Roche, 2004, p. 171). The city also benefitted from the Olympics, although it did not donate it. It is estimated that during the Games 5.000 new jobs were created in the city, although they were temporary (Baade, Matheson, 2002, p. 144). 


\section{CONCLUSION}

In the article an attempt to analyse the decision-making process of the communist states, the Soviet Union in particular, concerning the boycott of the Olympics in Los Angeles was undertaken. It was also aimed to investigate the actions undertaken by the organizers and the International Olympic Committee in order to prevent it - particularly the diplomatic efforts aimed to persuade as many communist and Third World countries to participate in the Games as possible. The results of the analysis seem to confirm the popular belief, that the boycott of the Olympic Games in 1984 by the communist states was in fact a payoff for the boycott of Moscow Games in 1980 by the capitalist states, even though the safety issue was declared as the official reason. Still, a statement that the boycott of the Los Angeles Olympics was a revenge for the boycott of Moscow Olympics is an oversimplification. According to many facts, the decisions concerning the boycott were made in the last moment, not in 1980. Moreover, both in the Soviet Union and in other communist countries the preparations to the Games were in progress for the whole 4-year period since the Moscow Olympics.

Many indicators point to the fact, that the decision concerning the boycott of the Los Angeles Olympic Games was affected by the changes of the Soviet leadership. L. Brezhnev was heading the Communist Party during the Moscow Olympics, then he was replaced by more liberal Y. Andropov. The latter one died a few months before the Los Angeles Olympics and the power was taken over by more radical K. Chernenko. After that moment a vast change of the Soviet attitude towards the Games could be seen. It appears then that the boycott was not certain and it was mostly affected by coincidental deaths of the consecutive Soviet leaders.

The efficacy of the boycott of the Los Angeles Olympic Games is doubtful, similarly to most of the previous sports boycotts. Only the African states proved to be relatively successful in using a sports boycott threat and eventually boycotting various sports events such as the Olympic Games in Montreal in 1976 or the Commonwealth Games in Edinburgh in 1986, as they managed to isolate internationally the states they contested - South 
Africa and Rhodesia, which were governed by ethnic white minorities. In this case, Communist states failed to achieve their objectives, such as ruining the Games financially or limiting Reagan's chance of re-election. In general though, sports boycotts do not bring political benefits and its main victims are the athletes from the boycotting countries.

Nowadays a classic sports boycott - a one that includes resignation of participating in a sports event due to political reasons by one or more states - seems rather improbable. Most of the boycotts turned out to be unsuccessful. Moreover, the economic significance of sport has risen in the last decades. Nevertheless, a sports boycott does not seem to be a dead tool of international politics, only its shape has changed. These days, if there are objections towards the country hosting a major sports event, boycotts still occur, only in a different way. Politicians, who normally participate in such events during for instance opening ceremonies, resign from this privilege. Such situations took place during recent Olympic Summer Games in Beijing in 2008 and Olympic Winter Games in Sochi in 2014. Such symbolic movement allows to express dissatisfaction concerning the policy of a particular nation without harming the athletes. Still, one cannot definitely exclude the possibility of a return of classical sports boycotts in the future. Such initiatives still do appear, for instance a discussion about the possibility of boycotting the Football World Championships in Russia in 2018 has arisen lately after a former Dutch footballer Johan van't Schip proposed it (Zech, 2014). Still, as for now it is unlikely that another classical sports boycott may occur in the near future.

\section{BIBLIOGRAPHY}

Baade R.A., Matheson V. (2002). Bidding for the Olympics: fool's gold?. In C. Pestana Barros, M. Ibrahimo, S. Szymanski (Eds.). Transatlantic Sport. The Comparatice Economics of North American and European Sports (p. 127-151). Cheltenham: Edward Elgar Pub.

Caraccioli T., Caraccioli J. (2008). Boycott. Stolen Dreams of the 1980 Moscow Olympic Games. Washington: New Chapter Press. 
Cheney G. (2005). Shot Down. Irvine: San Val.

Chruścicki B. (1987). Igrzyska u stóp Hollywood. Warszawa: Wydawnictwo „Sport i Turystyka”.

Delaney T., Madigan T. (2009). The Sociology of Sports. An Introduction. Jefferson: McFarland.

Espy R. (1981). The Politics of the Olympic Games. With Epilogue, 1976-1980. Berkeley: University of California Press.

Garcia M.A. (2012). Secrets of the Olympic Ceremonies. Lexington: MAG Publishing.

Gemmell, J. (2004). The Politics of South African Cricket. London: Routledge.

Glad B. (2009). An Outsider in the White House. Jimmy Carter, His Advisors, and the Making of American Foreign Policy. New York: Cornell University Press. Guelke, A. (1986, September). The Politicisation of South African Sport. In L. Allison (Ed.). The Politics of Sport (p. 118-148). Manchester: Manchester University Press

Guttmann A. (2002). The Olympics. A History of Modern Games. Illinois: University of Illinois Press.

Hill C.R. (1996). Olympic Politics. Athens to Atlanta 1896-1996. Manchester: Manchester University Press.

International Olympic Committee (2011). Olympic Summer Games. Fonds Lists. Lausanne: Historical Archive Olympic Studies Centre.

Jennings W. (2012). Olympic Risks. Basingstoke: Palgrave Macmillan.

Kumar A. (2007). Complete Book of Olympic Games. New Delhi: Khel Sahitya Kendra.

Lipoński W. (1996). Od Aten do Atlanty. Minihistoria nowożytnych igrzysk olimpijskich 1896-1996. Poznań: Atena.

Lipoński W. (2000). Olimpizm dla każdego. Poznań: Wydawnictwo AWF Poznań. Los Angeles 1984. (2015, March 18). Retrieved from http://www.olympic.org/ los-angeles-1984-summer-olympics

Mallon B., Heijmans J. (2011). Historical Dictionary of the Olympic Movement. Plymouth: Scarecrow Press.

Miller D. (2008). Historia Igrzysk Olimpijskich i MKOl. Od Aten do Pekinu 1894-2008. Poznań: Dom Wydawniczy Rebis. 
Moscow 1980. (2015, March 18). Retrieved from http://www.olympic.org/ moscow-1980-summer-olympics

'No hope' for Soviets in Olympics (1984, May 31). Spokane Chronicle (p. 8). Retrieved from https://news.google.com/newspapers?nid=1345\&dat=1984 0531\&id=91xOAAAAIBAJ\&sjid=i_kDAAAAIBAJ\&pg=7020,3493285\&hl=en Olszański T. (2000). Osobista Historia Olimpiad. Warszawa: Studio Emka.

Pietraś Z. (1998). Decydowanie polityczne. Warszawa: Wydawnictwo Naukowe PWN.

Polski Komitet Olimpijski. (1982). Polski Sport Olimpijski. Polish Olympic Sport. Los Angeles 1984. Warszawa: Wydawnictwo Polskiego Komitetu Olimpijskiego. Reich K. (1984, May 21). Doleful Days for the Games. Sports Illustrated, 60(20), $16-22$.

Roche M., (2004). Mega-Events and Media Culture: Sport and the Olympics. In D. Rowe (Ed.). Critical Readings: Sport, Culture and the Media (p. 165-182). Maidenhead: Open University Press.

Senn A. (1999). Power, Politics and the Olympic Games. A history of power brokers, events, and controversies that shaped the games. Champaign: Human Kinetics. Talk On Olympics Reported Slated with Gromyko (1984, May 28). The Blade: Toledo (p. 3). Retrieved from https://news.google.com/newspapers?nid=13 $50 \&$ dat $=19840528 \& \mathrm{id}=$ tU9PAAAAIBAJ $\&$ sjid $=$ wgIEAAAAIBAJ $\& p g=6823$, $1971738 \& \mathrm{hl}=\mathrm{en}$

Tomaszewski B. (1992). Przeżyjmy to jeszcze raz. Warszawa: BGW.

Toohey K., Veal A.J. (2007). The Olympic Games. A Social Science Perspective. Wallingford: Cabi.

Wawrzynowski M. (2015, February 9). Śmierć, złoto olimpijskie i zastrzyk dla konia - historia Janusza Peciaka. Retrived from http://s port.tvp.pl/18794361/ smierc-zloto-olimpijskie-i-zastrzyk-dla-konia-historia-janusza-peciaka.

Whitney C.R. (1980, January 21). Soviets are coming to Lake Placid no matter what. The Day, 38.

Wilson J. (1988). Politics and Leisure. Boston: Unwin Hyman.

Wilson W. (1996). Los Angeles 1984. In J.E. Findling, K.D. Pelle (Eds.). Historical Dictionary of Modern Olympic Movement (p. 169-178). Westport: Greenwood Publishing Group. 
Wilson W. (2004). Los Angeles 1984. In J.E. Findling, K.D. Pelle (Eds.), Encyclopedia of the Modern Olympic Movement (p. 207-217). Westport: Greenwood Publishing Group.

Zech, M. (2014, July 23). KNVB Asked to Toycott Russia, 2018 World Cup. Website of NL Times. Retrieved from http://www.nltimes.nl/2014/07/23/knv b-asked -boycott-russia-2018-world-cup/ 